\title{
Ground-based measurements of immersion freezing in the eastern Mediterranean
}

\author{
K. Ardon-Dryer ${ }^{1,2,{ }^{*}}$ and Z. Levin ${ }^{1,3}$ \\ ${ }^{1}$ Department of Geophysical, Atmospheric and Planetary Sciences, Tel Aviv University, Israel \\ ${ }^{2}$ The Porter School of Environmental Studies, Tel Aviv University, Israel \\ ${ }^{3}$ Energy, Environment and Water Research Center, The Cyprus Institute, Nicosia, Cyprus \\ *now at: Department of Earth, Atmospheric and Planetary Sciences, MIT, Cambridge, MA, USA
}

Correspondence to: K. Ardon-Dryer (karinard@ mit.edu)

Received: 3 December 2013 - Published in Atmos. Chem. Phys. Discuss.: 7 January 2014

Revised: 26 March 2014 - Accepted: 9 April 2014 - Published: 27 May 2014

\begin{abstract}
Ice nuclei were measured in immersion-freezing mode in the eastern Mediterranean region using the FRIDGE-TAU (FRankfurt Ice-nuclei Deposition freezinG Experiment, the Tel Aviv University version) chamber. Aerosol particles were sampled during dust storms and on clean and polluted days (e.g., Lag BaOmer). The aerosol immersion-freezing potential was analyzed in the laboratory using a drop-freezing method. Droplets from all the samples were found to freeze between $-11.8^{\circ} \mathrm{C}$ and $-28.9^{\circ} \mathrm{C}$. Immersion-freezing nuclei (FN) concentrations range between $0.16 \mathrm{~L}^{-1}$ and $234 \mathrm{~L}^{-1}$, while the activated fraction (AF) ranges between $8.7 \times 10^{-8}$ and $4.9 \times 10^{-4}$. The median temperature at which the drops from each filter froze was found to be correlated with the corresponding daily average of $\mathrm{PM}_{10}, \mathrm{PM}_{2.5}$ and $\mathrm{PM}_{10}-\mathrm{PM}_{2.5}$. A higher correlation value between $\mathrm{FN}$ concentrations and $\mathrm{PM}_{10}-\mathrm{PM}_{2.5}$ suggests that the larger particles are generally more effective as FN.

The measurements were divided into dust storms and "clean" conditions (this is a relative term, because dust particles are always present in the atmosphere is this region) based on the air mass back trajectories and the aerosol mass concentrations $\left(\mathrm{PM}_{10}\right)$. Droplets containing ambient particles from dust storm days froze at higher temperatures than droplets containing particles from clean days. Statistically significant differences were found between dust storms and clean conditions primarily in terms of the initial temperature at which the first drops froze, the median freezing temperature and the aerosol loading (PM values). FN concentrations and $\mathrm{AF}$ values in dust storms were larger by more than a factor of 2 than in the clean conditions. This observation agrees
\end{abstract}

with previous studies showing that some dust particles are almost always present in the atmosphere in this region.

Measurements of aerosol particles emitted from wood burning bonfires during a Lag BaOmer holiday showed that although a high concentration of particles was emitted, those particles' effectiveness as FN was relatively poor. The most likely reason for the low FN efficiency is the combination of relatively low fire temperatures and high organic carbon fraction in the aerosols.

\section{Introduction}

Ice plays an important role in the development of clouds and precipitation and in affecting the planet's albedo (IPCC, 2007). Ice in the atmosphere forms mainly by heterogeneous nucleation on aerosol particles called ice nuclei (IN). Heterogeneous ice nucleation can proceed through a number of mechanisms such as contact freezing that occurs when an ice nucleus initiates freezing by contacting a supercooled droplet, by condensation freezing that takes place following water condensation on the ice nucleus, by deposition nucleation that occurs when an ice embryo forms directly by water vapor condensation on the surface of the particle, and by immersion freezing when freezing of a water droplet occurs on a foreign particle immersed in it (Pruppacher and Klett, 1997). The concentrations and physical properties of these IN particles vary greatly from place to place and with weather conditions. 
The relative importance of the different freezing modes is not clear. In addition, our understanding of the physical and chemical processes underlying heterogeneous ice formation is limited (Niedermeier et al., 2010). Difficulties arise in quantifying the mechanisms of ice nucleation because of the varied composition, surface characteristics and size distributions of the IN (Kanji et al., 2011). In the last decade much attention has been given to laboratory studies on heterogeneous ice nucleation (e.g., Hoose and Möhler, 2012, and references therein) and to field studies (e.g., DeMott et al., 2003a, b; Prenni et al., 2009a, b; Klein et al., 2010a; Santachiara et al., 2010; Ardon-Dryer et al., 2011; Conen et al., 2012), all of which contributed greatly to our understanding of IN distribution in different parts of the world. In addition, analysis of the chemical composition of IN residuals from airborne measurements using electron microscopy and mass spectroscopy (e.g., Seifert et al., 2003; Cziczo et al., 2003, 2006, 2013; Froyd et al., 2010) have added a deeper understanding about the nature of some of the IN in the atmosphere.

Although biological particles have been found to be among the most efficient IN (e.g., Schnell and Vali, 1976; Levin and Yankofsky, 1983; Levin et al., 1987; Diehl et al., 2002), their concentrations in the atmosphere are relatively low. This makes them less likely to dominate the ice processes in clouds (Hoose et al., 2010). On the other hand, mineral dust aerosol particles are among the largest contributors to atmospheric aerosol (Goudie and Middleton, 2006). The presence of dust particles inside ice crystals suggests that ice nucleation is often initiated by mineral dust aerosol in the atmosphere (Isono, 1955; Isono et al., 1971; Kumai, 1961, 1976; Twohy and Poellot, 2005; Cziczo et al., 2013). In addition, many field studies show an increase of IN concentration during dust storms (e.g., Bowdle et al., 1985; DeMott et al., 2003a; Van den Heever et al., 2006; Chou et al., 2011), with increases as high as double (e.g., Levi and Rosenfeld, 1996) or even 5-fold (e.g., Klein et al., 2010a) compared to dust-free conditions.

Dust particles have been observed to nucleate ice at different heterogeneous nucleation modes: deposition nucleation (e.g., Möhler et al., 2006; Kulkarni and Dobbie, 2010; Kanji et al., 2013), condensation freezing (e.g., Roberts and Hallett, 1968; Levi and Rosenfeld, 1996; Zimmermann et al., 2008; DeMott et al., 2011), contact freezing (e.g., Pitter and Pruppacher, 1973; Ladino et al., 2011) and immersion freezing (e.g., Pitter and Pruppacher, 1973; Marcolli et al., 2007; Lüönd et al., 2010; Broadley et al., 2012; Pinti et al., 2012; Welti et al., 2012; Kanji et al., 2013). Zhang et al. (2012) concluded that dust particles play an important role in modifying mixed-phase cloud properties due to their ability to form ice. Moreover, Lohmann and Diehl (2006), using their parameterization of heterogeneous ice nucleation, found that dust particles can have a significant impact on the liquid water path, cloud lifetime, precipitation rate and top-of-the-atmosphere radiation.
Results from extensive IN measurements around the world have been published in the past few decades. However, only very few were reported from the eastern Mediterranean (e.g., Gagin, 1975; Levi and Rosenfeld, 1996). Gagin (1975) measured the concentrations of condensation freezing nuclei near the bases of cumulus clouds by using a thermal diffusion chamber at water saturation over the temperature range of $-5^{\circ} \mathrm{C}$ to $-25^{\circ} \mathrm{C}$. Ground measurements of IN concentration by Levi and Rosenfeld (1996), using a thermal diffusion chamber at $-15^{\circ} \mathrm{C}$, reported similar IN concentrations to those reported by Gagin (1975). Levi and Rosenfeld (1996) found that the concentration of IN during dust storm periods was more than double that found during non-dust-storm periods. Although immersion freezing has been shown to be the dominant mode of ice nucleation (e.g., Hoose et al., 2010), measurements of IN in this mode from the eastern Mediterranean area have never been reported.

The aim of the present study is to characterize the efficiency of IN in the eastern Mediterranean area in immersionfreezing mode during dust storm days and during days without dust storms.

\section{Characteristics of the research area}

The measurements were conducted from January 2009 to December 2010 in the eastern Mediterranean region on the Tel Aviv University campus, located in the northern part of Tel Aviv, Israel (Fig. 1). The sampling was conducted on the roof top of the Department of Geophysical, Atmospheric and Planetary Sciences ( $\left.32^{\circ} 6^{\prime} 46.7^{\prime \prime} \mathrm{N}, 34^{\circ} 48^{\prime} 22.9^{\prime \prime} \mathrm{E}\right)$, about $20 \mathrm{~m}$ above ground, $60 \mathrm{~m}$ above sea level and about $2.5 \mathrm{~km}$ from the seashore.

The eastern Mediterranean region is characterized by air masses arriving from different sources (Lelieveld et al., 2002). Many of these air masses often contain aerosol particles from distant and local anthropogenic sources (Levin and Lindberg, 1979; Graham et al., 2004). Some contain dust particles from the Sahara (Ganor, 1994; Levin et al., 2005), while others contain marine and biogenic aerosol from the Mediterranean Sea (Levin et al., 1990) and from land sources (Ganor et al., 2000). In some cases the desert dust particles undergo changes due to chemical processes (e.g., sulfate coating; Levin et al., 1996) and/or attachment to other particles such as sea salt (Levin et al., 2005).

Air masses reaching Tel Aviv from the northwest carry a larger fraction of marine aerosol, mainly sea spray and anthropogenic aerosol with a relatively small fraction of desert particles. Air masses reaching the measuring station from the southwest (the Sahara and North African deserts) carry a larger fraction of desert and marine aerosol, with a smaller fraction of anthropogenic particles (Levin et al., 1990, 2005). Dust also reaches Israel from the east, although dust storms from the North African (southwest) deserts are more common, with much lower visibility and much higher aerosol 


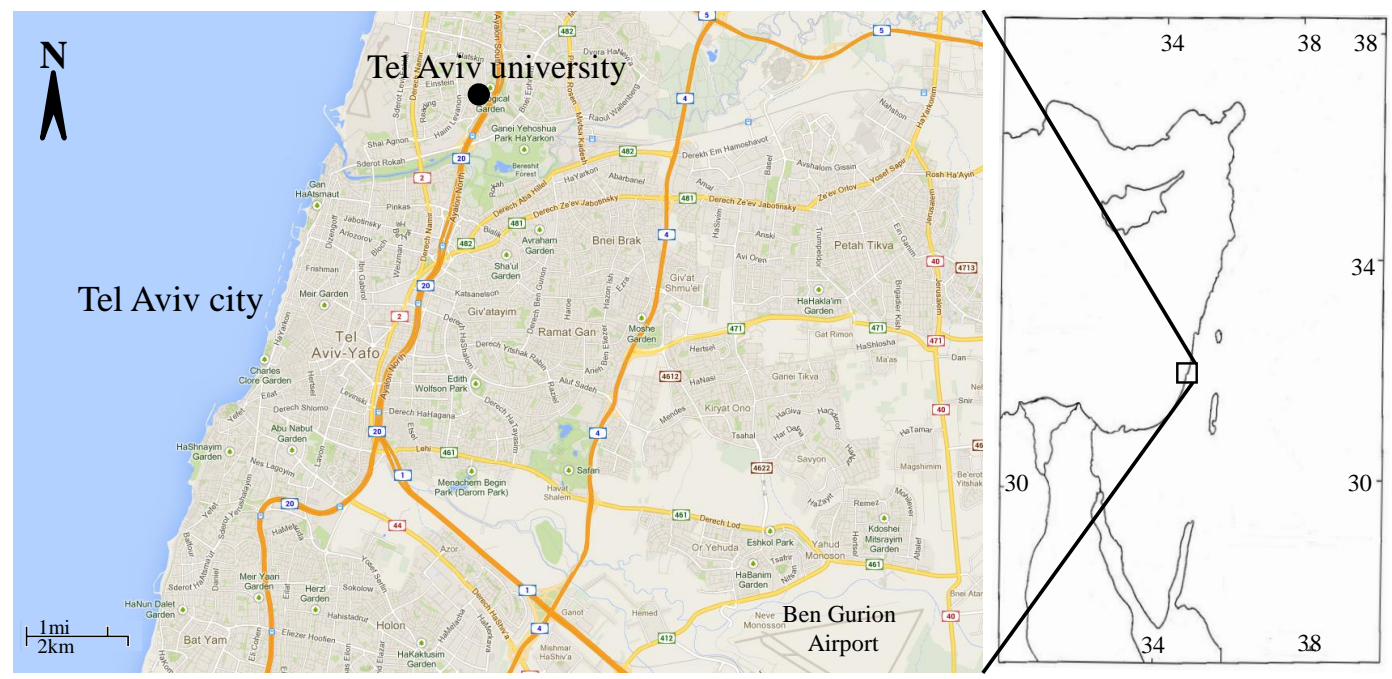

Figure 1. Location of the sampling station at Tel Aviv University marked in black (Google Maps, with modification, 2012).

loading (Ganor et al., 1991). Ganor and Foner (1996) showed that the chemical composition of dust transported from North Africa is similar to the dust transported from the east. Both dust sources contain soluble and insoluble inorganic material as well as organic matter, but they are distinguished by their clay mineralogy. These desert aerosol particles are mainly composed of quartz, calcite, dolomite, feldspars, gypsum and clay minerals (Ganor and Mamane, 1982). Ganor (1994) found an average of 19 dust storms per year based on 33 years of observations. Dust storms are most common between December and April (Katznelson, 1970), with maxima occurrences in spring time, mainly during April (Ganor, 1994). During the summer very few dust storms occur (Ganor et al., 1991). Although mineral dust particles are present in high concentrations during dust storms, such mineral dust particles are almost always present in the atmosphere in this region (Levin and Lindberg, 1979).

Every year for one day during the month of May the eastern Mediterranean area is filled with biomass burning particles due to the Lag BaOmer (LBO) event. LBO is a national Israeli holiday in which many people set bonfires in open spaces around the country. The event starts usually at sunset (around 19:00 local time, LT) and lasts throughout most of the night (usually until sunrise). Most of the bonfires burn dry processed Finnish pine wood taken from construction sites. Often the heavy smoke is generated from low-temperature smoldering combustion, which would be classified as type A (extinguishable by water; Boothroyd, 2005). The high level of pollution due to these fires can be detected from satellites (Kaufman et al., 2006). LBO events have been studied in the past (e.g., Sarnat et al., 2010; von Schneidemsser et al., 2010), including studies of the particles' chemical aging and optical properties (e.g., Adler et al., 2011). However, no studies have been reported on the properties of these particles as IN.

\section{Method of analysis}

A total of 19 filter samples were collected during January 2009 to December 2010. The aerosol particles were sampled for $20 \mathrm{~min}$ on nitrocellulose membrane black filters of $47 \mathrm{~mm}$ diameter and $0.45 \mu \mathrm{m}$ pore size, which were held in a standard Millipore open metal holder type with a flow rate of $20 \mathrm{LPM}$ (total of $400 \mathrm{~L}$ on each filter). The open inlet of the filter holder was facing down, with the holder itself being held at a distance of $1.5 \mathrm{~m}$ from the floor. Table 1 presents a list of the filters that were sampled during days that were classified (see below the classification criteria for each case) as dust storms, clean and polluted days (e.g., LBO) and days that did not fit either the dust storm or clean conditions.

The aerosol total concentration was measured with TSI condensation particle counter (CPC) model 3010, which was located next to the filter sampler. In order to measure the concentration of particles in the size range of $0.11-3 \mu \mathrm{m}$, a TSI particle size selector model 376060 was used, with a number of screens placed in the front in order to remove particles smaller than $0.112 \mu \mathrm{m}$. With this instrument the total number concentration $(\mathrm{Nt})$ of the aerosol particles in this size range was measured and used to calculate the activated fraction (AF) values of the immersion-freezing nuclei (\#IN/Nt). In addition, at the beginning of the measurement period in January 2009 and for a relatively short time afterwards, a passive cavity aerosol spectrometer probe 100X (PCASP-100X) was used on a daily basis to measure aerosol size distributions in the range of 0.1 to $3 \mu \mathrm{m}$.

Aerosol mass concentrations of $\mathrm{PM}_{10}$ and $\mathrm{PM}_{2.5}$ (particulate matter with an aerodynamic diameter of less than $10 \mu \mathrm{m}$ and $2.5 \mu \mathrm{m}$, respectively) were also used. These data were downloaded from the website of the Ministry of Environmental Protection (http://www.svivaaqm.net/Default.rtl. aspx). The $\mathrm{PM}_{10}$ data were taken from Yad Avner station 
Table 1. List of filters sampled, total concentrations of particles and PM values with standard deviation.

\begin{tabular}{|c|c|c|c|c|c|}
\hline \# & $\begin{array}{l}\text { Date of } \\
\text { filter }\end{array}$ & $\begin{array}{c}\mathrm{CPC}_{3010} \text { number } \\
\text { concentration }\left(\# / \mathrm{cm}^{3}\right)\end{array}$ & $\begin{array}{c}\mathrm{PM}_{10} \text { day } \\
\text { average }\left(\mu \mathrm{g} \mathrm{m}^{-3}\right)\end{array}$ & $\begin{array}{c}\mathrm{PM}_{2.5} \text { day } \\
\text { average }\left(\mu \mathrm{g} \mathrm{m}^{-3}\right)\end{array}$ & Classification \\
\hline 1 & 24 Jan 2009 & $640 \pm 35$ & $842 \pm 620$ & $212 \pm 153$ & Dust storm \\
\hline 2 & 15 Feb 2009 & $727 \pm 101$ & $245 \pm 127$ & $44 \pm 22$ & Dust storm \\
\hline 3 & 19 Feb 2009 & $1251 \pm 67$ & $442 \pm 506$ & $100 \pm 94$ & Dust storm \\
\hline 4 & 8 Mar 2009 & $516 \pm 27$ & $318 \pm 174$ & $77 \pm 38$ & Not classified \\
\hline 5 & 15 Mar 2009 & $1964 \pm 226$ & $39 \pm 13$ & $13 \pm 5$ & Clean \\
\hline 6 & 16 Jun 2009 & $1159 \pm 24$ & $35 \pm 11$ & $20 \pm 7$ & Clean \\
\hline 7 & 21 Sep 2009 & $841 \pm 81$ & $30 \pm 9$ & $22 \pm 11$ & Clean \\
\hline 8 & 22 Oct 2009 & $423 \pm 43$ & $31 \pm 12$ & $21 \pm 12$ & Clean \\
\hline 9 & 1 Nov 2009 & $1865 \pm 101$ & $84 \pm 42$ & $21 \pm 9$ & Not classified \\
\hline 10 & 17 Dec 2009 & $1826 \pm 329$ & $678 \pm 494$ & $154 \pm 105$ & Dust storm \\
\hline 11 & 30 Jan 2010 & $718 \pm 153$ & $383 \pm 426$ & $60 \pm 53$ & Dust storm \\
\hline 12 & 09 Mar 2010 & $1600 \pm 66$ & $408 \pm 229$ & $84 \pm 44$ & Dust storm \\
\hline 13 & 11 Apr 2010 & $437 \pm 55$ & $352 \pm 469$ & $73 \pm 78$ & Dust storm \\
\hline 14 & 1 May 2010_15* & $564 \pm 15$ & $36 \pm 9$ & $21 \pm 7$ & Clean \\
\hline 15 & 1 May 2010_23* & $1345 \pm 97$ & $36 \pm 9$ & $21 \pm 7$ & Lag BaOmer \\
\hline 16 & 27 May 2010 & $752 \pm 46$ & $867 \pm 745$ & $155 \pm 131$ & Dust storm \\
\hline 17 & 15 Nov 2010 & $2626 \pm 54$ & $94 \pm 21$ & $45 \pm 19$ & Not classified \\
\hline 18 & 30 Dec 2010 & $1552 \pm 172$ & $89 \pm 21$ & $30 \pm 9$ & Not classified \\
\hline 19 & 31 Dec 2010 & $612 \pm 31$ & $49 \pm 28$ & $21 \pm 11$ & Not classified \\
\hline
\end{tabular}

* Two samples were collected on the same day (1 May 2010) at 15:00 LT and at 23:00 LT (during Lag BaOmer celebration).

$\left(32^{\circ} 7^{\prime} 9.4^{\prime \prime} \mathrm{N} 34^{\circ} 48^{\prime} 17.9^{\prime \prime} \mathrm{E}\right)$ located about $700 \mathrm{~m}$ north of the sampling station. The $\mathrm{PM}_{2.5}$ data were taken from Municipal High School Ironi D station ( $\left.32^{\circ} 5^{\prime} 34.9^{\prime \prime} \mathrm{N}, 34^{\circ} 47^{\prime} 27.5^{\prime \prime} \mathrm{E}\right)$ located about $2.5 \mathrm{~km}$ southwest of the sampling site. This monitoring station was chosen because it is the closest to our measuring station and because it is located at a similar distance from the coastline. Aerosol number concentration and aerosol mass concentration $\left(\mathrm{PM}_{10}\right.$ and $\left.\mathrm{PM}_{2.5}\right)$ are also listed in Table 1.

The immersion-freezing measurements were conducted using the FRIDGE-TAU (FRankfurt Ice-nuclei Deposition freezinG Experiment, the Tel Aviv University version) chamber (See Fig. 2 in Ardon-Dryer et al., 2011). This chamber, which is usually used for studying ice formation by deposition and by condensation freezing (Bundke et al., 2008; Klein et al., 2010b), was used here to determine the temperature at which freezing of drops containing aerosol particles took place.

Each filter containing the collected aerosol was placed in $10 \mathrm{~mL}$ of double-distilled water (resistivity of $18.2 \mathrm{M} \Omega \mathrm{cm}$ ). The aerosol particles were then removed from the filter by means of an ultrasonic shaker. The use of the ultrasonic shaker was found to be effective for particle removal into the water solution. This method, which is more aggressive than the removal method used by Vali (1968), was found to be effective in removing all of the most effective particles after only one cycle of shaking in the ultrasonic bath. The resulting mixture of water and aerosol was the source of the drops tested for immersion freezing. Each test consisted of about 140 drops ( $1 \mu \mathrm{L}, 0.8 \mathrm{~mm}$ diameter) placed by a pipette on the temperature controlled stage of the FRIDGE-TAU. A thin layer of Vaseline was first put on the stage in order to prevent ice from forming on the surface during cooling. This was necessary to prevent the formation of very thin ice dendrites that grow by vapor deposition from the perimeter of some frozen drops, reaching and freezing some of their neighbors, thus affecting the measurements. The temperature of the cooling stage was lowered at a constant rate of $1^{\circ} \mathrm{C} \mathrm{min}^{-1}$ and the number of drops that froze at each temperature was recorded by a CCD (charge-coupled device) camera.

In most cases the filters were cut in half before being placed in $10 \mathrm{~mL}$ of double-distilled water. This was done in order to be able to duplicate the measurements if needed. In some cases the unused half of the filter was used for elemental analysis of individual particles with an environmental scanning electron microscope (ESEM) with an attached $\mathrm{X}$-ray energy dispersive system (EDS). The exceptions were the filters from the 24 January 2009, 19 February 2009 and 17 December 2009, which were not cut and were immersed in the distilled water and in the ultrasonic shaker.

\subsection{Calculation of immersion-freezing nuclei (FN) concentration}

In order to estimate the concentrations of immersion $\mathrm{FN}$ in the air we converted Vali's (1971) equation taking into account the amount of air that had been sampled in each measurement. The equation is composed of two parts: the first is 

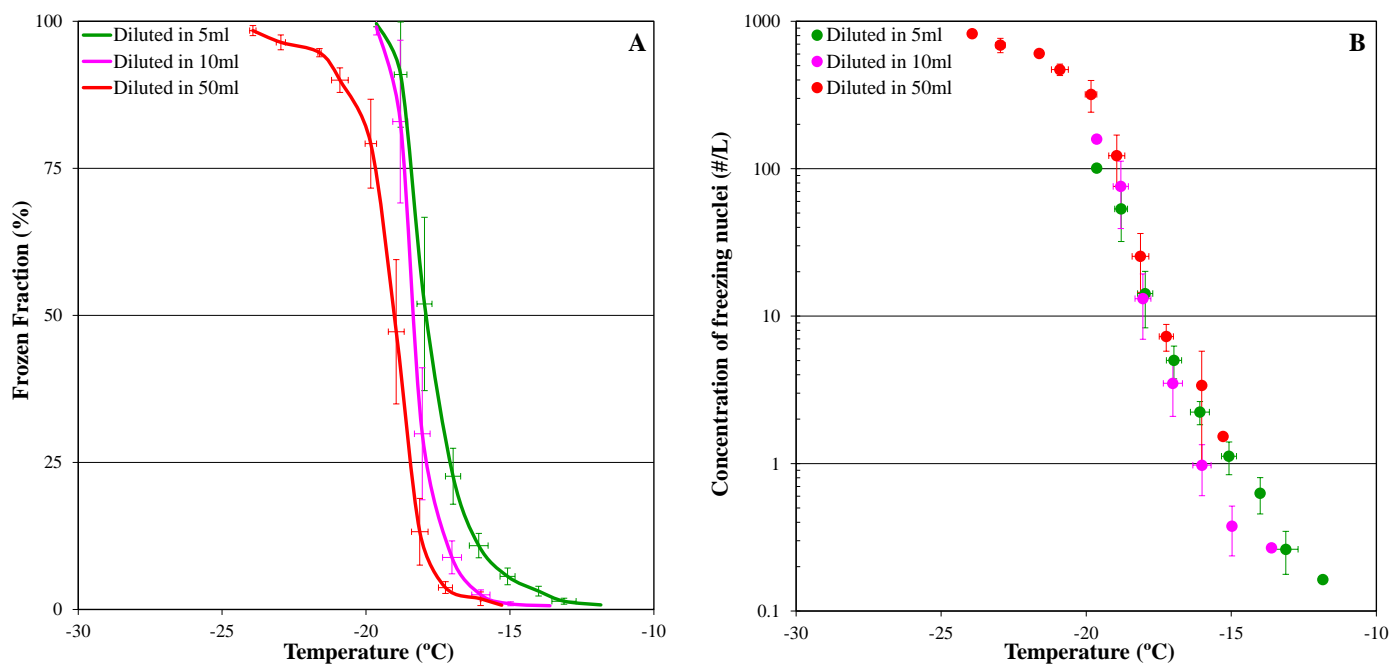

Figure 2. Results of freezing experiments using montmorillonite particles. (A) Cumulative frozen fraction as a function of temperature of all three dilution experiments. (B) FN concentration calculated as a function of temperature for the different dilution experiments.

an integration of the differential probability that a drop will freeze at temperatures between $T$ and $T-\Delta T$ due to the presence of a single active nucleus in it over the temperature range from $0{ }^{\circ} \mathrm{C}$ to $T$. The result of the integration is the cumulative nucleus concentration $\mathrm{K}^{\prime}(T)$, which represents the number of nuclei active at all temperatures higher than $T$. In order to obtain the actual concentrations of IN in the sampled air, consideration must be given to the total air sampled. This is presented in the last part of the equation:

$$
K^{\prime}(T)=\frac{1}{V} \times\left[\ln \left(N_{0}\right)-\ln (N(T))\right] \times \frac{x}{y},
$$

where $\mathrm{K}^{\prime}(T)$ is the cumulative concentration of FN in the air active at temperature $T\left(\mathrm{~L}^{-1}\right), V$ is the volume of the drop (L), $N_{0}$ is the total number of drops measured, $N(T)$ is the number of unfrozen drops at temperature $T, x$ is the volume of water used to remove the particles from the filter (L), and $y$ is the volume of air sampled through the filter $(\mathrm{L})$.

Equation (1) was verified and found to be a reliable equation based on laboratory measurements of montmorillonite particles (SWy-2 Na-montmorillonite) on one filter. Three experiments were made with the same filter in which we diluted the concentration of the aerosol particles in the sample three successive times and analyzed them each time in immersion-freezing mode. The dilution was done by placing the filter in the test tube and deposited the particles into $5 \mathrm{~mL}$ of double-distilled water. Drops from this sample were analyzed in the immersion-freezing mode. Then another $5 \mathrm{~mL}$ of water was added (total of $10 \mathrm{~mL}$ without extra shaking) and drops from this mixture were analyzed. Finally $40 \mathrm{~mL}$ of water was added to the same tube (total of $50 \mathrm{~mL}$ without extra shaking) followed by analysis of drop freezing. The cumulative freezing spectra of the three experiments are shown in Fig. 2. As expected, the more diluted the sample, the bigger the shift of the cumulative spectrum to lower temperatures. The reason for this is that the dilution decreases the probability that a good IN will be present in the drop. However, converting these cumulative results to $\mathrm{FN}$ concentrations in the air based on Eq. (1) gives very similar concentrations. The montmorillonite onset freezing temperature (the temperature at which the first drop freezes) was similar to the onset freezing temperature of Zimmermann et al. (2008), Hoffer (1961) and Salam et al. (2007).

\section{Results and discussion}

Nineteen filters from different days were sampled under different conditions, as can be seen in Table 1. A total of 2720 drops was analyzed. All drops, regardless of the sample used, froze between $-11.8^{\circ} \mathrm{C}$ and $-28.9^{\circ} \mathrm{C}$, with median freezing that varied from $-17.8^{\circ} \mathrm{C}$ down to $-24.4^{\circ} \mathrm{C}$, as can be seen from Table 2. The freezing of all drops from the sampled filters occurred at higher temperatures compared to water drops taken from pure water, or those taken from the blank filters. It should be noted, however, that a small overlap between the blank filters and the sampled ones was observed at temperatures between $-23^{\circ} \mathrm{C}$ and $-29^{\circ} \mathrm{C}$. The overlap amounted to a total of 196 droplets, comprising $7.2 \%$ of the total drop population. This means that about $7.2 \%$ of the drops could freeze at these temperatures even in the absence of aerosol. Therefore, in the following analysis, the fraction of drops from the sampled filters that froze at the same temperature as the blank have been removed. The effect of the reduction on the calculated concentrations was small, from $0.1 \%$ to $11.4 \%$ over the temperature range in the experiment. After the subtraction of these drops, the median temperature shifted by an average of $0.18^{\circ} \mathrm{C}$. 
Table 2. Results of the onset of freezing temperature, median temperature and the temperature of the last freezing drop in each sample. List of the freezing spectra of all measured filters and the average spectrum of freezing temperature from clean (blank) filters and blank (pure) water.

\begin{tabular}{llrrr}
\hline Filter & Date & $\begin{array}{r}\text { Onset of } \\
\text { freezing }\end{array}$ & $\begin{array}{r}\text { Median } \\
\text { freezing }\end{array}$ & $\begin{array}{r}\text { Freezing temperature } \\
\text { of the last drop } \\
\text { temperature }\left({ }^{\circ} \mathrm{C}\right)\end{array}$ \\
\hline 1 & 24 Jan 2009 & -15.6 & -20.1 & -24.1 \\
temperature $\left({ }^{\circ} \mathrm{C}\right)$ & -25.5 \\
2 & 15 Feb 2009 & -12.8 & -21.1 & -22.6 \\
3 & 19 Feb 2009 & -16.0 & -19.9 & -26.8 \\
4 & 08 Mar 2009 & -15.8 & -21.7 & -21.4 \\
5 & 15 Mar 2009 & -15.3 & -20.5 & -28.9 \\
6 & 16 Jun 2009 & -19.7 & -24.4 & -25.6 \\
7 & 21 Sep 2009 & -18.9 & -22.1 & -26.3 \\
8 & 22 Oct 2009 & -15.9 & -20.3 & -25.3 \\
9 & 1 Nov 2009 & -15.0 & -21.2 & -21.5 \\
10 & 17 Dec 2009 & -12.8 & -17.8 & -23.1 \\
11 & 30 Jan 2010 & -15.5 & -20.8 & -24.2 \\
12 & 09 Mar 2010 & -14.8 & -19.7 & -24.0 \\
13 & 11 Apr 2010 & -16.9 & -21.7 & -26.1 \\
14 & 01 May 2010_15 & -15.5 & -22.2 & -26.6 \\
15 & 01 May 2010_23 & -17.9 & -21.7 & -23.8 \\
16 & 27 May 2010 & -11.8 & -19.3 & -24.8 \\
17 & 15 Nov 2010 & -16.0 & -21.4 & -25.6 \\
18 & 30 Dec 2010 & -17.7 & -22.0 & -26.7 \\
19 & 31 Dec 2010 & -17.8 & -21.6 & -40.0 \\
& Blank (clean)water & -23.0 & -32.3 & -40.0 \\
\hline & Blank filter & -26.0 & -35.6 & \\
\hline
\end{tabular}

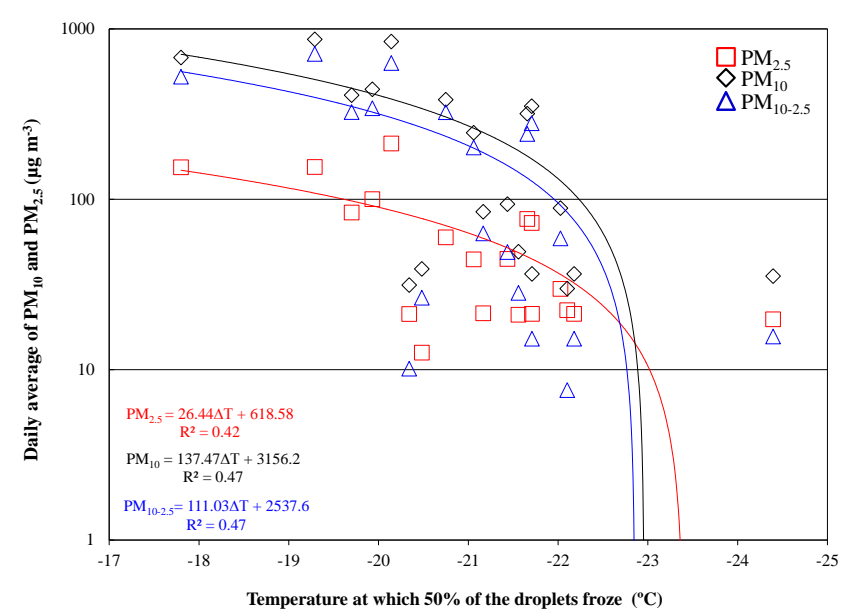

Figure 3. The connection between the median freezing temperature of the drops and the daily average values of $\mathrm{PM}_{2.5}$ (in red), $\mathrm{PM}_{10}$ (in black), and $\mathrm{PM}_{10}-\mathrm{PM}_{2.5}$ (in blue).

The drops containing the collected ambient particles began to freeze at lower temperatures than those reported from some biological aerosol such as bacteria and leaf litters (e.g., Schnell and Vali, 1976; Maki and Willoughby, 1978; Schnell et al., 1982; Levin and Yankofsky, 1983). Freezing was found to occur at higher temperatures than those reported by Ardon-Dryer et al. (2011) for the South Pole. Most onset freezing temperatures in this work were lower than those measured by Conen et al. (2012) at the high-Alpine research station Jungfraujoch in the Swiss Alps. It is interesting to point out that Kanitz et al. (2011) and Seifert et al. (2010) observed a relatively high fraction of ice in mid-level stratiform clouds with cloud top temperatures as warm as $-10^{\circ} \mathrm{C}$ or even higher when dust particles were present. This is very similar to the results of Levin et al. (1996), who reported on ice concentrations in eastern Mediterranean convective clouds. It is also in good agreement with the present results showing the effectiveness of the mineral dust particles as FN at such warm temperatures.

The median freezing temperatures of the droplets in each case were found to be correlated with the corresponding daily average values of $\mathrm{PM}_{10}, \mathrm{PM}_{2.5}$ and $\mathrm{PM}_{10}-\mathrm{PM}_{2.5}$ (see Fig. 3). The correlation value of $\mathrm{PM}_{2.5}\left(R^{2}=0.42\right)$ was lower than those measured for $\mathrm{PM}_{10}$ and $\mathrm{PM}_{10}-\mathrm{PM}_{2.5}\left(R^{2}=0.47\right)$. This suggests that the more effective freezing nucleation is associated with the larger particles, those that fall into the range $\mathrm{PM}_{10}-\mathrm{PM}_{2.5}$. Furthermore, as the aerosol concentration increased, the median freezing temperatures of the droplets became higher. These results are in agreement with many other reports (e.g., Garten and Head, 1964; Philips et al., 2008; Welti et al., 2009; Klein et al., 2010b; Niedermeier et al., 2011) showing the correlation between IN concentrations 


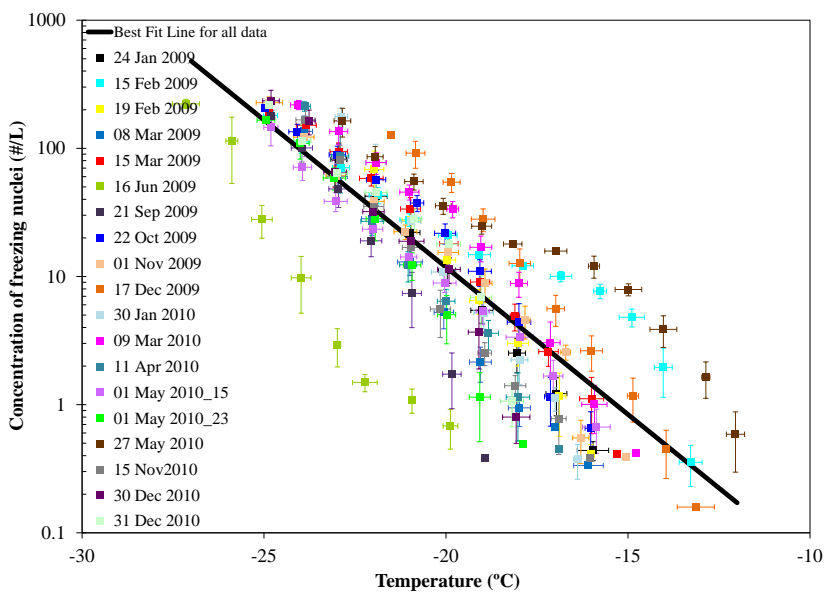

Figure 4. The concentrations of FN using the different filters. The bars represent the standard deviation and the black line is the bestfit line representing all the data. Please note the significantly low values of the measurements during the Lag BaOmer bonfires at 23:00 LT (green squares).

and the surface area of the particles. It is important to note that the dust storms in this region often cover vast areas. Of course, some spatial variations in concentrations are expected, which could explain the lower correlations between the ice nuclei measurements and the PM values.

The FN concentration of all the samples was calculated based on Eq. (1). The FN concentration varied from $0.16 \mathrm{~L}^{-1}$ to $234 \mathrm{~L}^{-1}$, as can be seen in Fig. 4 . As expected, the concentration of active nuclei increases as the temperature decreases. Calculating the best-fit line (black line in Fig. 4) from the entire data results in an exponential equation:

$N_{\mathrm{FN}}=3 \times 10^{-4} e^{0.53 \Delta T}$,

where $N_{\mathrm{FN}}$ represents the concentrations of $\mathrm{FN}\left(\mathrm{L}^{-1}\right)$ and $\Delta T$ represents the supercooling in degrees Celcius. With this equation a concentration of $1 \mathrm{~L}^{-1}$ is reached at $-15.3^{\circ} \mathrm{C}$. This temperature is higher than the average temperature obtained by Bigg and Stevenson's (1970) measurements of condensation freezing that were taken around the world. These values are also higher than the condensation freezing measurements of Gagin (1975) that were observed in Israel $\left(\sim 1 \mathrm{~L}^{-1}\right.$ at $\left.-18.4^{\circ} \mathrm{C}\right)$.

$\mathrm{AF}$ values of all the filters were also calculated based on the total aerosol concentration in the size range of $0.11-3 \mu \mathrm{m}$, which were measured simultaneously with the filters. The average $\mathrm{AF}$ value of all the filters was $4.9 \times 10^{-5} \pm 8.1 \times 10^{-5}$ (average \pm standard deviation value) with variations from $8.7 \times 10^{-8}$ to $4.9 \times 10^{-4}$, as can be seen in Fig. 5. All the activated fraction values were combined and a best-fit line was calculated (see black line in Fig. 5). The majority of the AF values were in the range of values $\left(10^{-3}-10^{-6}\right.$, for particle $>0.1 \mu \mathrm{m})$ proposed by Pruppacher and Klett (1997). How-

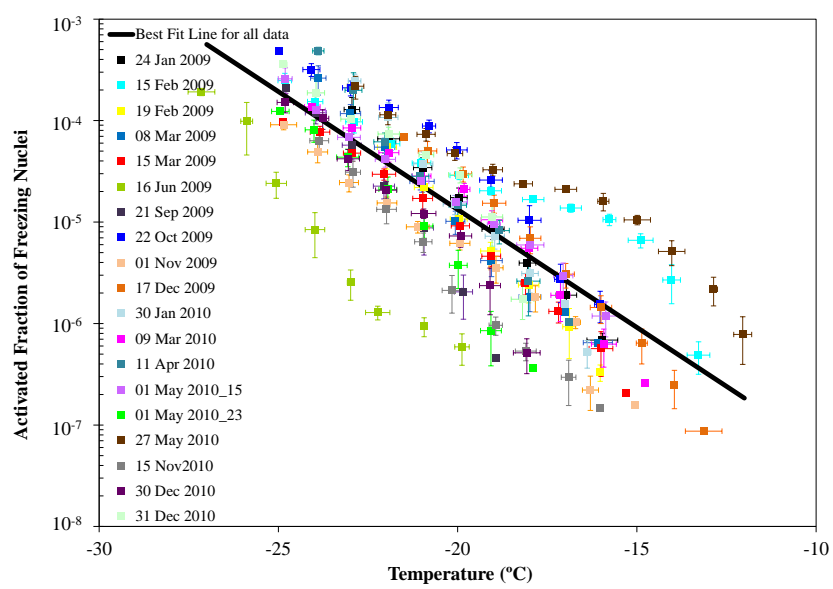

Figure 5. Activated fraction of FN calculated with standard deviation values for the different filters. Each color represents a different sample, and the black line is the best-fit line.

ever, the lowest AF value was much lower than that reported by Pruppacher and Klett (1997).

The concentration of FN and the values of AF increased as the temperatures decreased; the relatively high correlation values (>0.65) imply a strong dependence of FN on temperature. Similar dependence was observed in many previous publications (e.g., Meyers et al., 1992; Vali, 2008; Niedermeier et al., 2010). It is important to note that the lack of a clear temperature dependence of ice crystal concentrations in clouds (Gultepe et al., 2001) suggests that other parameters such as the chemistry of the aerosol, their surface area (Philips et al., 2008) and the concentration of particles larger than $0.5 \mu \mathrm{m}$ (DeMott et al., 2010) also play an important role in the nucleation.

\subsection{Immersion-freezing nuclei during dust storms and clean conditions}

The filter samples were separated into dust storms and clean conditions based on $\mathrm{PM}_{10}$ values and the air mass back trajectory. The back trajectories (BT) were calculated for each measurement using the HYSPLIT method (Hybrid Single Particle Lagrangian Integrated Trajectory Model). Dust storm days were defined as days when the $\mathrm{PM}_{10}$ daily average values and the value measured during the aerosol sampling time exceeded $100 \mathrm{\mu g} \mathrm{m}^{-3}$ (Ganor et al., 2009). In addition, the air mass trajectory in the previous $72 \mathrm{~h}$ had to have originated over a dust source or passed over one. Samples were defined as clean days when $\mathrm{PM}_{10}$ daily average values and the value measured during the aerosol sampling were below $50 \mu \mathrm{g} \mathrm{m}^{-3}$ (Ganor et al., 2009) and the air mass trajectory in the previous $72 \mathrm{~h}$ did not pass over a source of dust. It is obvious that classifying the atmospheric conditions as "clean" is relative compared to many other locations, because even in the absence of dust storms, mineral dust particles are always present in the air in this region. It should be noted 


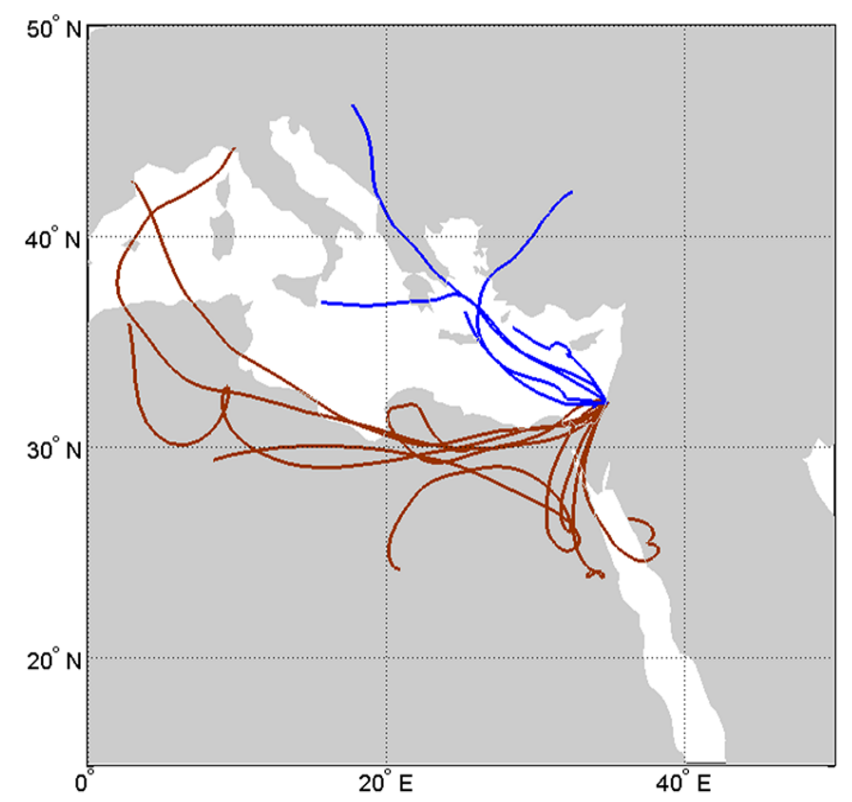

Figure 6. Back-trajectory history of air masses showing passage of air prior to reaching the sampling station. Each line represents a $72 \mathrm{~h}$ trajectory at $500 \mathrm{~m}$ altitude. The back trajectories were taken from http://www.arl.noaa.gov. The brown lines represent dust storm conditions and the blue lines represent clean conditions.

that in the research area, the yearly average standard values of $\mathrm{PM}_{10}$ is $60 \mathrm{\mu g} \mathrm{m}^{-3}$ (Israel Ministry of Environmental Protection, 2013), while in Europe the yearly average standard values of $\mathrm{PM}_{10}$ is $40 \mu \mathrm{g} \mathrm{m}^{-3}$ (Environment, 2014) and in the US it is $50 \mu \mathrm{g} \mathrm{m}^{-3}$ (EPA, 2014).

Out of all the days that were sampled, eight days were defined as dust storm days with daily average values of $\mathrm{PM}_{10}$ from 254 to $867 \mu \mathrm{g} \mathrm{m}^{-3}$, with an overall average of $527 \pm 236$. Five days were defined as clean days, with $\mathrm{PM}_{10}$ daily averages ranging from 30 to $39 \mu \mathrm{g} \mathrm{m}^{-3}$, with an overall average of $34 \pm 4$, as can be seen in Table 3 . In the clean cases the air mass arrived from the west or northwest, while on the dust storm days the air mass arrived from the south or southwest, as can be seen in Fig. 6.

Determinations of FN and AF during dust storm days were based on a total of 1173 droplets, while the clean days were based on 626 droplets. The onset of drop freezing of samples from the dust storm days started at $-11.8^{\circ} \mathrm{C}$ and freezing continued until $-25.1^{\circ} \mathrm{C}$, while for the clean days the onset of drop freezing started at temperature $-15.3^{\circ} \mathrm{C}$ and the last drop froze at $-27.4^{\circ} \mathrm{C}$, as can be seen in Table 3. The median freezing temperature of the dust storm days occurred at $1.8^{\circ}$ higher compared to the clean days. Significant statistical difference (based on a $t$ test) was found between the dust storm and the clean conditions in terms of onset of drop freezing, the median freezing temperatures and the aerosol mass loading (PMs).
FN concentrations (Fig. 7a) and AF values (Fig. 7b) were calculated separately for the clean and dust storm conditions. FN concentrations in dust storms ranged from $0.16 \mathrm{~L}^{-1}$ to $218 \mathrm{~L}^{-1}$, while the AF values ranged from $8.7 \times 10^{-8}$ to $4.9 \times 10^{-4}$. In the clean conditions FN concentrations ranged from $0.4 \mathrm{~L}^{-1}$ to $222 \mathrm{~L}^{-1}$, with the corresponding $\mathrm{AF}$ values ranging from $2.1 \times 10^{-7}$ to $4.9 \times 10^{-4}$. Best-fit lines representing dust storm and clean conditions were calculated. Figure 7 shows that the FN concentrations and AF values of the dust storm days were higher by more than a factor of 2 compared with the clean days. Similar increases were found by Levi and Rosenfeld (1996) in their measurements in the same region. It is interesting to point out that the differences between clean and dust storm conditions in regions where dust is less common, such as Florida and central Europe, are much greater (DeMott et al., 2003a; Klein et al., 2010b). The relatively small increase in FN concentrations and $\mathrm{AF}$ values that were found between the clean and dust storm conditions led us to investigate whether there is a difference (in FN concentrations and $\mathrm{AF}$ values) between the two conditions. FN concentrations and AF values in the dust storm and clean conditions did not show a significant statistical difference (based on a $t$ test). This suggests that dust particles are always present in the eastern Mediterranean atmosphere, even on days without dust storms, as was found by Levin and Lindberg (1979).

Single-particle analyses using the ESEM with an attached $\mathrm{X}$-ray energy dispersive system were performed on two samples collected on filters during two days (27 May 2010 and 15 November 2010). A total of 203 particles were analyzed, and the frequency of occurrence of the different elements is presented in Table 4. The air mass trajectories on these two days originated from dust sources; thus the presence of dust particles was expected. Ca was the most abundant element, and it was found in most of the particles $(>90 \%)$. Al, Si and $\mathrm{Fe}$ were found in somewhat fewer particles (>50\%). According to Falkovich et al. (2001), mineral dust particles in the eastern Mediterranean contain $\mathrm{Si}, \mathrm{Al}, \mathrm{Mg}, \mathrm{K}, \mathrm{Ca}$ and $\mathrm{Fe}$. Out of all the particles that were analyzed, $28 \%$ contained all these elements. Some of the dust particles also contained sulfate and $\mathrm{NaCl}$. The presence of sulfate and sea salt on dust particles has been reported in the past by Levin et al. (1996) and Levin et al. (2005), respectively. Many particles (48\% of the particles from 15 November 2010) were identified as calcite minerals. Some of the particles $(4 \%)$ contained $\mathrm{Ca}$ together with S, suggesting the presence of gypsum (Levin and Lindberg, 1979; Levin et al., 1996). Such a combination could also originate from a mixture of dust with anthropogenic pollution according to Graham et al. (2004). A few of the particles were identified as clay minerals (montmorillonite and illite) and a few others as feldspars. These findings are in agreement with those of Ganor (1991) and Ganor et al. (2009), who found montmorillonite, calcite, gypsum, illite and feldspar in particles from dust storms in the eastern Mediterranean area. 
Table 3. Summary of clean and dust storms conditions.

\begin{tabular}{lrr}
\hline Date & Dust storm days & Clean days \\
\hline Number of days & 8 & 5 \\
Average $\mathrm{PM}_{10}$ values $\left(\mu \mathrm{g} \mathrm{m}^{-3}\right)$ & $527 \pm 236$ & $34 \pm 4$ \\
Average $\mathrm{PM}_{2.5}$ values $\left(\mu \mathrm{g} \mathrm{m}^{-3}\right)$ & $110 \pm 58$ & $19 \pm 4$ \\
Average $\mathrm{PM}_{10-2.5 \text { values }\left(\mu \mathrm{g} \mathrm{m}^{-3}\right)}$ & $417 \pm 182$ & $15 \pm 7$ \\
Number of droplets used & 1173 & 626 \\
Temperature at which the first drops froze $\left({ }^{\circ} \mathrm{C}\right)$ & -11.8 & -15.3 \\
Median temperature of frozen drops $\left({ }^{\circ} \mathrm{C}\right)$ & $-20.0 \pm 1.0$ & $-21.9 \pm 2.0$ \\
Temperature at which the last drop froze $\left({ }^{\circ} \mathrm{C}\right)$ & -25.1 & -27.4 \\
\hline
\end{tabular}
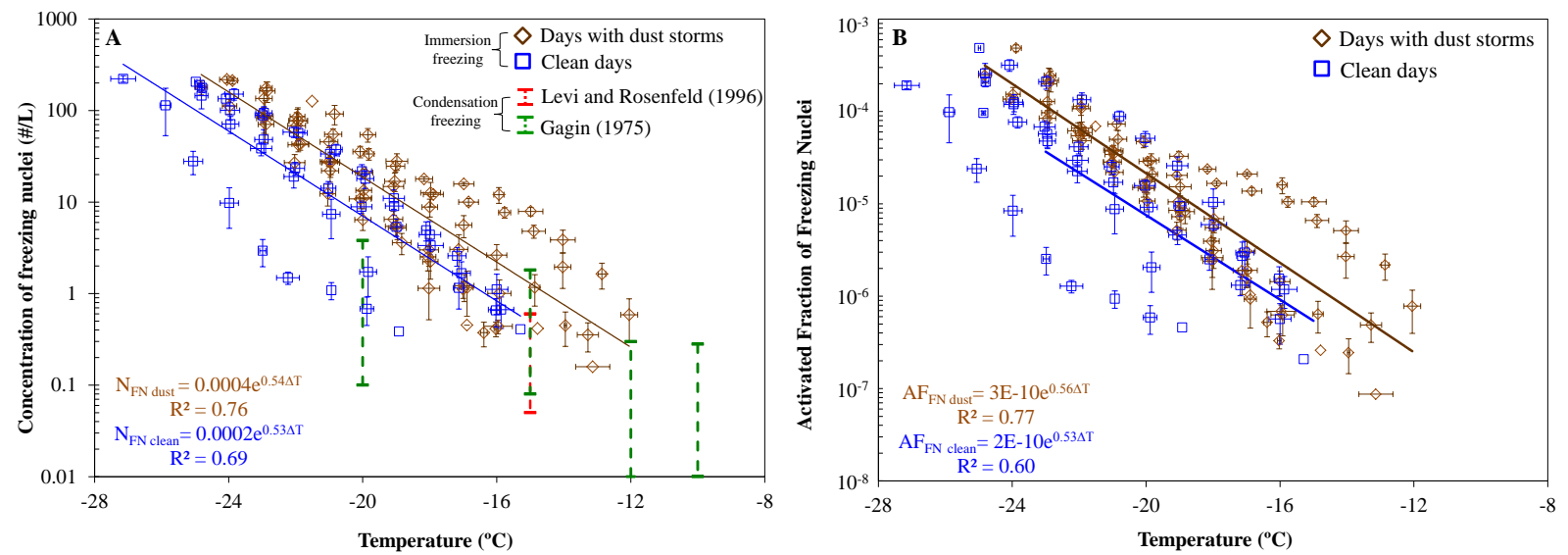

Figure 7. Freezing nuclei concentration (A) and activated fraction values (B) with standard deviation, calculated for clean (blue) and dust storm (brown) days. Best-fit lines and the equations that represent them are also shown. For comparison in (A) the ice nuclei concentrations measured in Israel near cloud base by Gagin (1975) (green bars) and ground measurements by Levi and Rosenfeld (1996) (red bars) are also shown.

Figure 7 also shows a comparison of FN concentration from dust storms and clean conditions and the measurements of ice nucleation by condensation freezing taken in the same research area by Levi and Rosenfeld (1996) and Gagin (1975). The figure shows some agreement between the two modes of nucleation at the higher temperatures, while there are differences of about one order of magnitude at lower temperatures. One possible explanation for this difference is that immersion freezing is more effective than condensation freezing. On the other hand, it is also possible that the difference is a result of the measuring method.

In order to compare the present results with results from laboratory studies, there was a need to calculate the ice nucleation active surface site (INAS) densities, (e.g Hoose and Möhler, 2012; Murray et al., 2012, and references therein).

\subsubsection{Calculation of ice nucleation active surface site densities}

In order to calculate the INAS densities, measurements of size distributions were needed. In addition, to the total aerosol concentration that was measured in the size range of 0.11 to $3 \mu \mathrm{m}$ by the CPC, at the beginning of the mea- surement period in January 2009 and for a relatively short time afterwards, a PCASP-100X was used on a daily basis to measure aerosol size distributions in the range of 0.1 to $3 \mu \mathrm{m}$. Due to instrumental difficulties, data from the PCASP were obtained during only four days defined as clean cases and only three days that were classified as dust storm days.

Figure 8 presents the average size distribution on the dust storm days as well as the average size distribution on the clean days. From these measurements the average total particle concentration in the size range of $0.5-3 \mu \mathrm{m}$ for the clean cases was $2 \pm 1 \mathrm{~cm}^{-3}$, while for dust storm cases it was $21 \pm 9 \mathrm{~cm}^{-3}$. For comparison, the present results are superimposed on the distributions of dust reported by Levin et al. (1980). Out of these seven days only two filter samples in dust storms events (15 and 19 February 2009) were collected simultaneously by the CPC and the PCASP instruments. It is clear that our measured distributions in the dust storms cases are very similar to those measured many years ago in the eastern Mediterranean and in other locations.

Due to the fact that the size distributions on the three dust storm days were very similar to each other and also similar to the other dust storms that were measured in the past, it was 
Table 4. Frequency of occurrence (\%) of elemental composition of 203 individual particles from two samples collected on 27 May and 15 November 2010, as measured by individual particle analysis using an ESEM and EDS.

\begin{tabular}{lr}
\hline Elements & $\begin{array}{r}\text { Frequency of } \\
\text { occurrence }(\%)\end{array}$ \\
\hline Calcium $(\mathrm{Ca})$ & 93.1 \\
Silicon $(\mathrm{Si})$ & 67.5 \\
Aluminum $(\mathrm{Al})$ & 59.6 \\
Iron $(\mathrm{Fe})$ & 50.7 \\
Magnesium $(\mathrm{Mg})$ & 45.3 \\
Potassium $(\mathrm{K})$ & 31.5 \\
Chlorine $(\mathrm{Cl})$ & 16.3 \\
Sulfur $(\mathrm{S})$ & 7.4 \\
Titanium $(\mathrm{Ti})$ & 3.9 \\
Sodium $(\mathrm{Na})$ & 3.4 \\
Bromine $(\mathrm{Br})$ & 3.4 \\
Barium $(\mathrm{Ba})$ & 1.0 \\
Molybdenum $(\mathrm{Mo})$ & 1.0 \\
Zinc $(\mathrm{Zn})$ & 0.5 \\
Copper $(\mathrm{Cu})$ & 0.5 \\
Manganese $(\mathrm{Mn})$ & 0.5 \\
\hline
\end{tabular}

decided to use the ratio of the data from the PCASP and the CPC as a scaling factor to estimate the size distribution on days during which no data from the PCASP were available.

The following ratio was calculated to provide a scaling factor between the CPC and PCASP total counts:

$\bar{X}_{\text {dust }}=N t_{(\text {PCASP } 0.11-3)} / N t_{(\mathrm{CPC} 0.11-3)}$.

Then we calculated the fraction of particles in the 0.5 to $3 \mu \mathrm{m}$ in the PCASP measurements:

$\bar{Y}_{\text {dust }}=N t_{(\text {PCASP0.5-3) }} / N t_{(\text {PCASP0.11-3) }}$.

The average number of particles per size from the days in which the PCASP data are available is given by:

$\bar{Z}_{i(\mathrm{PCASP} 0.5-3)}=\frac{n_{i}}{N t_{(\mathrm{PCASP} 0.5-3)}}$,

where $n_{i}$ is aerosol number concentration per size $i$ on days when PCASP data were available. Based on these scaling factors, one can estimate the number of particles in each size on days when only the CPC data were available:

$n_{i}^{*}=\bar{X}_{\mathrm{dust}} * \bar{Y}_{\mathrm{dust}} * \bar{Z}_{i(\mathrm{PCASP} 0.5-3)} * N_{T \_\mathrm{CPC}}^{*}$,

where $n_{i}^{*}$ is aerosol number concentration per size $i$ on days when no PCASP data were available. $N_{T}^{*}{ }_{C P C}$ is the total aerosol number concentrations $\left(\mathrm{cm}^{-3}\right)$ measured by the CPC. The same procedure was not followed for the clean days because the size distribution on the days on which PCASP data were available varied greatly, with some days

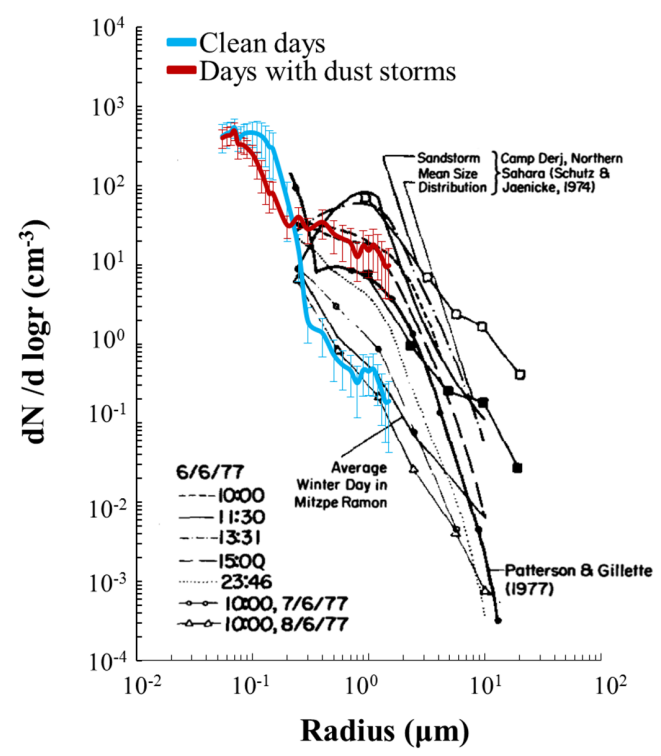

Figure 8. Average size distributions and standard deviation as measured during dust storm and clean days (in brown and blue, respectively) plotted on top of the results of dust particle measurements in Israel and in other locations as presented by Levin et al. (1980).

having larger particles present while on others much narrower distributions were measured.

With these calculated size distributions the ice nucleation active surface site densities were calculated. The INAS density describes the number of ice nucleation active sites at a certain temperature and supersaturation, normalized by the aerosol surface area. Due to the fact that this experiment was carried out in the immersion-freezing mode, the calculations were done assuming the nucleation occurred under water saturation. The INAS was calculated using the method proposed by Hoose and Möhler (2012):

$n_{\mathrm{S}}(T)=-1 / A_{\mathrm{aer}} * \ln \left(1-f_{\mathrm{IN}}(T)\right)$,

where $f_{\mathrm{IN}}$ is the ice nucleation active fraction under the considered conditions. In our case the AF was calculated for particles larger than $0.5 \mu \mathrm{m}$ as measured by the PCASP or scaled by the method above. $A_{\text {aer }}$ is the aerosol surface per particle, which is equal to the total surface area of all the particles (assuming they are spherical) divided by the total aerosol number concentration.

INAS density values for the dust storm cases range from $1.1 \times 10^{5}$ to $4.9 \times 10^{9}$, as can be seen in Fig. 9. The results from the immersion freezing in this work fall well within the range of measurements presented by Hoose and Möhler (2012). The steep increase in INAS density values with lowering of temperature (Fig. 9) agrees well with the results of Connolly et al. (2009), Niedermeier et al. (2010) and Murray et al. (2011), who compared the values of INAS of different mineral dusts in the laboratory. It is interesting to point out 


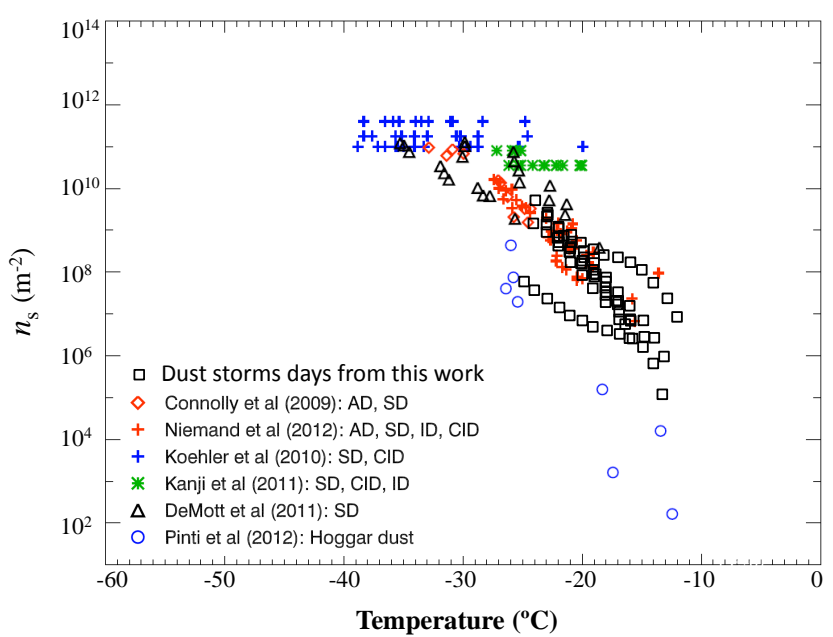

Figure 9. INAS densities as a function of temperature from Hoose and Möhler (2012), with dust storm days from this work in black squares. It is worth noting the similarity between the present results from immersion freezing and those obtained by means of a different nucleation mode and using different types of desert dusts such as Asian dust (AD), Canary Island dust (CID), Saharan dust (SD) and Israeli dust (ID).

that one dust sample that was measured by Niedermeier was a sample of Israeli dust (see Fig. 9).

\subsection{The Lag BaOmer bonfires}

On 1 May 2010 we had an opportunity to sample the FN concentration during the LBO holiday. Aerosol particles for FN measurements were sampled a few hours before the start of the LBO bonfires (15:00 LT) and during the event itself (1 May 2010, 23:00 LT). The smell of smoke was present in the air even though the sampling station was a few kilometers away from any bonfires. The total particle concentration in addition to $\mathrm{PM}_{10}$ and $\mathrm{PM}_{10-2.5}$ values increased during the time that the bonfires were lit. This can be seen in Fig. 10, where $\mathrm{PM}_{10}, \mathrm{PM}_{10-2.5}$ and total particle concentrations are presented. It is important to note that these lowtemperature fires produced high concentrations of particles, many of which were larger than $2.5 \mu \mathrm{m}$, as can be seen in the values of $\mathrm{PM}_{10-2.5}$.

The effectiveness of biomass burning in producing IN concentrations has been studied by a number of groups in the past. However, a wide range of results about the effectiveness of these particles as IN can be found in the literature. For example, Hobbs and Locatelli (1969) measured downwind of a natural forest fire in Stampede Pass in the state of Washington. These fires burn lodgepole pine and white pine and produce heavy smoke with high concentrations of IN. Similarly, Pratt et al. (2011), who measured smoke from mountain sagebrush plumes in Wyoming, observed significant increases in IN concentrations. On the other hand, some reports show that certain types of fires, such as smoldering combus-

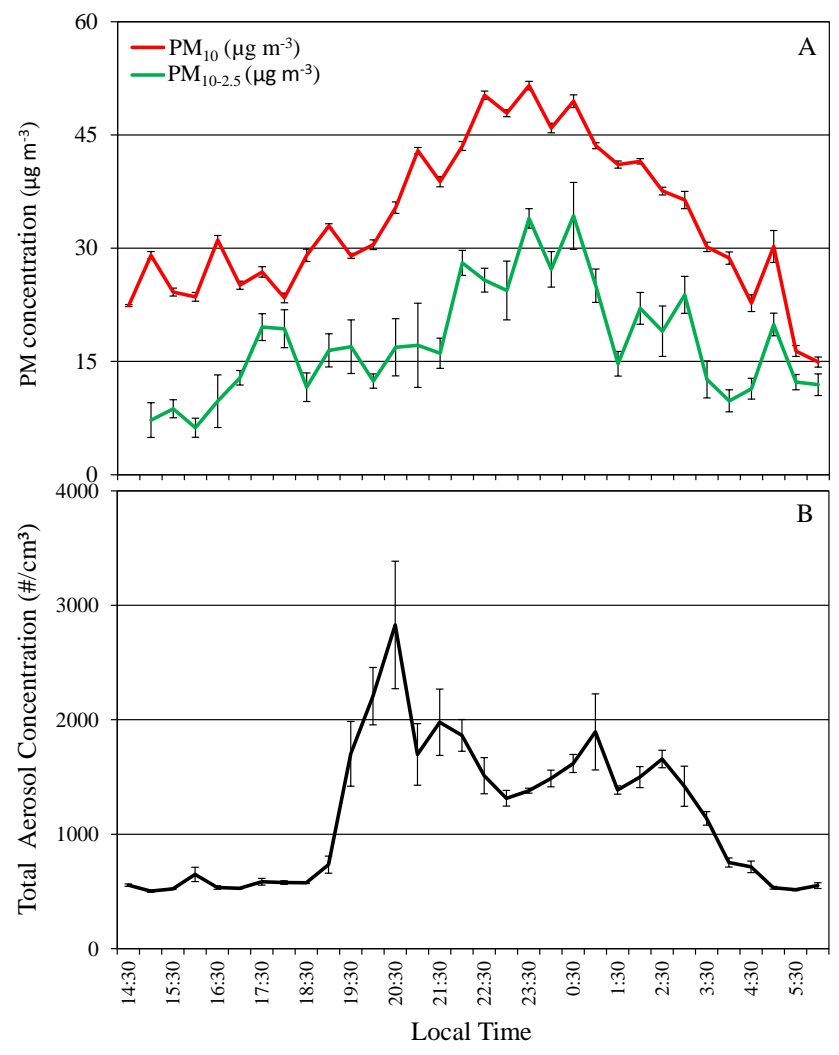

Figure 10. $\mathrm{PM}_{10}$ (in red) and $\mathrm{PM}_{10-2.5}$ concentration (in green) and aerosol total concentration (in black), as measured during 1-2 May 2010. The data are averaged over $30 \mathrm{~min}$ and the bars represent the standard deviation. The bonfires started around 19:00 LT and ended around 03:00 LT the next morning as rain began to fall.

tion, produce particles that are not as effective as IN (Prenni et al., 2012). Petters et al. (2009) concluded that emissions from fires with a low organic carbon fraction, high watersoluble ion content and high burning temperatures are associated with a larger amount of IN. Since most of the wood types used in the LBO fires are different from the ones studied before, it was interesting to study its effectiveness as a source of IN.

We observed that at the temperature at which the particles nucleated ice, the AF and the FN concentrations before the LBO bonfires (15:00 LT) were higher compared to those measured during the event itself (23:00 local LT). For example, $1 \mathrm{~L}^{-1}$ was measured before $\mathrm{LBO}$ at $-16.5^{\circ} \mathrm{C}, 1.5^{\circ} \mathrm{C}$ higher than the one measured during the fires themselves (as can be seen in Fig. 4). The AF over the whole temperature range before LBO was about 4 times higher than during the holiday bonfires. In summary, our measurements agree with the conclusions of Petters et al. (2009) that the low concentration of IN during the LBO event is due to the combination of the relatively low temperatures of the fires and the high organic carbon fraction in the fires as were measured by Adler et al. (2011). In summary, although the bonfires on 
LBO produced numerous particles, their effectiveness as FN is relatively poor.

\section{Conclusions}

FN concentrations were measured from samples collected on different days in the eastern Mediterranean region during January 2009 to December 2010. Drops containing ambient aerosol particles were found to freeze between $-11.8^{\circ} \mathrm{C}$ and $-28.9^{\circ} \mathrm{C}$, with median freezing temperature that varied from $-17.8^{\circ} \mathrm{C}$ to $-24.4^{\circ} \mathrm{C}$. $\mathrm{FN}$ concentrations range between $0.16 \mathrm{~L}^{-1}$ and $234 \mathrm{~L}^{-1}$, while the AF ranges from $8.7 \times 10^{-8}$ to $4.9 \times 10^{-4}$. The median temperature at which the drops from each filter froze were found to be correlated with the corresponding daily average of $\mathrm{PM}_{10}, \mathrm{PM}_{2.5}$ and $\mathrm{PM}_{10}-\mathrm{PM}_{2.5}$. The fact that the correlation value between $\mathrm{FN}$ concentrations and $\mathrm{PM}_{10}-\mathrm{PM}_{2.5}$ was higher than $\mathrm{PM}_{2.5}$ suggests that the larger particles are generally more effective as FN. This is in agreement with the notion that the activity of ice nucleation is correlated with surface area.

Classification of part of the samples into dust storm and clean conditions (this is a relative term, because dust particles are always present in the atmosphere is this region) was based on their back trajectory and aerosol mass concentrations $\left(\mathrm{PM}_{10}\right)$. Droplets containing ambient particles from dust storm days froze at higher temperatures than droplets containing particles from clean days. The difference between the clean and dust storm days was significant statistically in terms of onset of drop-freezing temperature, median freezing temperature and aerosol concentration (PMs). FN concentrations and $\mathrm{AF}$ values in dust storms were larger by more than a factor of 2 than in the clean conditions. This observation agrees with previous studies showing that some dust particles are almost always present in the atmosphere in this region.

It was observed that although the bonfires during the Lag BaOmer holiday produce high concentrations of aerosol particles, their effectiveness as FN was relatively poor. The reason for this stems from the relatively low fire temperatures and high organic carbon fraction in the particles.

Acknowledgements. We would like to acknowledge the GermanIsraeli Foundation (GIF) for their support (grant number 1-860-27) and H. Bingemer, H. Klein, U. Bundke, W. Haunold, R. Sitalh, A. Danielczokand and J. Schrod from the Institute for Atmospheric and Environmental Sciences, Goethe-University, Frankfurt, Germany, for all the help and support with the FRIDGE-TAU chamber. Thanks are due to the students I. Silver and R. Jaijel from Tel Aviv University and to S. Garimella from MIT for their help with the sampling and the analysis.

We want to thank the reviewer P. DeMott and two anonymous reviewers as well as the editor of this paper for their very constructive comments, which helped improve the paper. In addition, thanks are due to G. Vali and to P. Seifert for their comments.

Edited by: B. Ervens

\section{References}

Adler, G., Flores, J. M., Abo Riziq, A., Borrmann, S., and Rudich, Y.: Chemical, physical, and optical evolution of biomass burning aerosols: a case study, Atmos. Chem. Phys., 11, 1491-1503, doi:10.5194/acp-11-1491-2011, 2011.

Ardon-Dryer, K., Levin, Z., and Lawson, R. P.: Characteristics of immersion freezing nuclei at the South Pole station in Antarctica, Atmos. Chem. Phys., 11, 4015-4024, doi:10.5194/acp-11-40152011, 2011.

Bigg, E. K. and Stevenson, C. M.: Comparison of ice nuclei in different parts of the world, J. Rech. Atmos., 4, 41-58, 1970.

Broadley, S. L., Murray, B. J., Herbert, R. J., Atkinson, J. D., Dobbie, S., Malkin, T. L., Condliffe, E., and Neve, L.: Immersion mode heterogeneous ice nucleation by an illite rich powder representative of atmospheric mineral dust, Atmos. Chem. Phys., 12, 287-307, doi:10.5194/acp-12-287-2012, 2012.

Boothroyd, T.: Fire Detection and Suppression Systems, Intl Fire Service Training Assn, USA, 2005.

Bowdle, D. A., Hobbs, P. V., and Radke, L. F.: Particles in the Lower Troposphere over the High Plains of the United States. Part III: Ice Nuclei, J. Clim. Appl. Meteorol., 24, 1370-1376, 1985.

Bundke, U., Nillius, B., Jaenicke, R., Wetter, T., Klein, H., and Bingemer, H.: The fast ice nucleus chamber FINCH, Atmos. Res., 90, 180-186, 2008.

Chou, C., Stetzer, O., Weingartner, E., Jurányi, Z., Kanji, Z. A., and Lohmann, U.: Ice nuclei properties within a Saharan dust event at the Jungfraujoch in the Swiss Alps, Atmos. Chem. Phys., 11, 4725-4738, doi:10.5194/acp-11-4725-2011, 2011.

Conen, F., Henne, S., Morris, C. E., and Alewell, C.: Atmospheric ice nucleators active $\geq-12{ }^{\circ} \mathrm{C}$ can be quantified on $\mathrm{PM}_{10}$ filters, Atmos. Meas. Tech., 5, 321-327, doi:10.5194/amt-5-321-2012, 2012.

Connolly, P. J., Möhler, O., Field, P. R., Saathoff, H., Burgess, R., Choularton, T., and Gallagher, M.: Studies of heterogeneous freezing by three different desert dust samples, Atmos. Chem. Phys., 9, 2805-2824, doi:10.5194/acp-9-2805-2009, 2009.

Cziczo, D. J., DeMott, P. J., Brock, C. A., Hudson, P. K., Jesse, B., Kreidenweis, S. M., Prenni, A. J., Schreiner, J., Thomson D. S., and Murphy D. M.: A method for single particle mass spectrometry of ice nuclei, Aerosol. Sci. Tech., 37, 460-470, 2003.

Cziczo, D. J., Thomson, D. S., Thompson, T. L., DeMott P. J., and Murphy D. M.: Particle analysis by laser mass spectrometry (PALMS) studies of ice nuclei and other low number density particles, Int. J. Mass Spectrom., 258, 21-29, 2006.

Cziczo, D. J., Froyd, K. D., Hoose, C., Jensen, E. J., Diao, M., Zondlo, M. A., Smith, J. B, Twohy, C. H., and Murphy, D. M: Clarifying the Dominant Forces and Mechanisms of Cirrus Cloud Formation, Science, 340, 1320-1324, 2013.

DeMott, P. J., Sassen, K., Poellet, M. R., Baumgardner, D., Rogers, D. C., Brooks, S. D., Prenni, A. J., and Kreidenweis, S. M.: African dust aerosols as atmospheric ice nuclei, Geophys. Res. Lett., 30, 1732, doi:10.1029/2003GL017410, 2003a.

DeMott, P. J, Cziczo, D., Prenni, A., Murphy, D., Kreidenweis, S., Thomson, D., Borys, R., and Rogers, D.: Measurements of the concentration and composition of nuclei for cirrus formation, $\mathrm{P}$. Nat. Acad. Sci. USA, 100, 14655-14660, 2003 b.

DeMott, P. J., Prenni, A. J., Liu, X., Kreidenweis, S. M., Petters, M. D., Twohy, C. H., Richardson, M. S., Eidhammer, T., and Rogers, D. C.: Predicting global atmospheric ice nuclei distributions and 
their impacts on climate, P. Natl. Acad. Sci. USA., 107, 1121711222, 2010.

DeMott, P. J., Möhler, O., Stetzer, O., Vali, G., Levin, Z., Petters, M. D., Murakami, M., Leisner, Th., Bundke, U., Klein, H., Kanji, Z. A., Cotton, R., Jones, H., Benz, S., Brinkmann, M., Rzesanke, D., Saathoff, H., Nicolet, M., Saito, A., Nillius, B., Bingemer, H., Abbatt, J. P. D., Ardon, K., Ganor, E., Georgakopoulos, D. G., and Saunders, C.: Resurgence in ice nuclei measurement research, B. Am. Meteorol. Soc., 92, 1623-1635, doi:10.1175/2011BAMS3119.1, 2011.

Diehl, K., Matthias-Maser, S., Jaenicke, R., and Mitra, S. K.: The ice nucleating ability of pollen: Part II. Laboratory studies in immersion and contact freezing modes, Atmos. Res., 61, 125-133, 2002.

Environment, Air Quality Standards, http://ec.europa.eu/ environment/air/quality/standards.htm (last access: 13 April 2014), 2014.

EPA, Particulate Matter (PM-10), http://www.epa.gov/airtrends/ aqtrnd95/pm10.html (last access: 13 April 2014), 2014.

Falkovich, A., Ganor, E., Levin, Z., Formenti P., and Rudich, Y.: Chemical and mineralogical analysis of individual mineral dust particles, J. Geophys. Res., 106, 18029-18036, 2001.

Froyd, K. D., Murphy, D. M., Lawson, P., Baumgardner, D., and Herman, R. L.: Aerosols that form subvisible cirrus at the tropical tropopause, Atmos. Chem. Phys., 10, 209-218, doi:10.5194/acp10-209-2010, 2010.

Gagin, A.: The Ice Phase in Winter Continental Cumulus Clouds, J. Atmos. Sci., 32, 1604-1614, 1975.

Ganor, E.: The Frequency of Saharan Dust episodes over Tel-Aviv, Israel, Atmos. Environ., 28, 2867-2871, 1994.

Ganor, E. and Foner, H.: The mineralogical and chemical properties and the behavior of the aeolian Saharan dust over Israel, in: The Impact of Desert Dust Across the Mediterranean, edited by: Guerzoni, S. and Chester, R., Kluwer Academic Publishers, the Netherlands, 163-172, 1996.

Ganor, E. and Mamane, Y.: Transport of Saharan dust across the eastern Mediterranean, Atmos. Environ., 16, 581-587, 1982.

Ganor, E., Foner, H. A., Brenner, S., Neeman, E., and Lavi, N.: The chemical composition of aerosols settling in Israel following dust storm, Atmos. Environ., 25A, 2665-2670, 1991.

Ganor, E., Foner, H. A., Bingemer, H. G., Udiste, R., and Setter, I.: Biogenic sulfate generation in the Mediterranean Sea and its contribution to the sulfate anomaly in the aerosol over Israel and eastern Mediterranean, Atmos. Environ., 34, 3453-3462, 2000.

Ganor, E., Stupp, A., and Alpert, P.: A method to determine the effect of mineral dust aerosols on air quality, Atmos. Environ., 43, 5463-5468, 2009.

Garten, V. A. and Head, R. B.: Carbon Particles and Ice Nucleation, Nature, 201, 1091-1092, 1964.

Google maps: https://maps.google.com/ (last access: 10 November 2012), 2012.

Goudie, A. S. and Middleton, N. J.: Desert Dust in the Global System, Springer Berlin Heidelberg, New York, 2006.

Graham, B., Falkovich, A. H., Rudich, Y., Maenhaut, W., Guyon, P., and Andreae, M. O.: Local and regional contributions to the atmospheric aerosol over Tel Aviv, Israel: a case study using elemental, ionic and organic tracers, Atmos. Environ., 38 15931604,2004
Gultepe, I., Isaac, G. A., and Cober, S. G.: Ice crystal number concentration versus temperature for climate studies, Int. J. Climatol., 21, 1281-1302, 2001.

Hobbs, P. V. and Locatelli, J. D.: Ice nuclei from a natural forest fire, J. Appl. Meteorol., 8, 833-834, 1969.

Hoffer, T.: A laboratory investigation of droplet freezing, J. Meteorol., 18, 766-778, 1961.

Hoose, C., Kristjánsson, J. E., and Burrows, S. M.: How important is biological ice nucleation in clouds on a global scale? Environ. Res. Lett., 5, 024009, doi:10.1088/1748-9326/5/2/024009, 2010.

Hoose, C. and Möhler, O.: Heterogeneous ice nucleation on atmospheric aerosols: a review of results from laboratory experiments, Atmos. Chem. Phys., 12, 9817-9854, doi:10.5194/acp-12-98172012, 2012.

IPCC, Climate Change 2007: The Physical Science Basis, Contribution of Working Group I to the Fourth Assessment Report of the Intergovernmental Panel on Climate Change, Paris, 2007.

Isono, K.: On ice crystal nuclei and other substances found in snow crystals, J. Meteorol., 12, 456-462, 1955.

Isono, K., Komabayasi, M., Takeda, T., Tanaka, T., Iwai, K., and Fujiwara M.: Concentration and nature of ice nuclei in rim of the North Pacific Ocean, Tellus, 23, 40-59, 1971.

Israel Ministry of Environmental Protection, http://www.sviva.gov. il/subjectsEnv/SvivaAir/Laws/Pages/toxicityvalue.aspx (last access: 10 May 2013), 2013 (in Hebrew).

Kanitz, T., Seifert, P., Ansmann, A., Engelmann, R., Althausen, D., Casiccia, C., and Rohwer, E. G.: Contrasting the impact of aerosols at northern and southern midlatitudes on heterogeneous ice formation, Geophys. Res. Lett., 38, L17802, doi:10.1029/2011GL048532, 2011.

Kanji, Z. A., DeMott, P. J., Möhler, O., and Abbatt, J. P. D.: Results from the University of Toronto continuous flow diffusion chamber at ICIS 2007: instrument intercomparison and ice onsets for different aerosol types, Atmos. Chem. Phys., 11, 31-41, doi:10.5194/acp-11-31-2011, 2011.

Kanji, Z. A., Welti, A., Chou, C., Stetzer, O., and Lohmann, U.: Laboratory studies of immersion and deposition mode ice nucleation of ozone aged mineral dust particles, Atmos. Chem. Phys., 13, 9097-9118, doi:10.5194/acp-13-9097-2013, 2013.

Katznelson, J.: Frequency of dust storms at Be'er Sheva, Israel, J. Earth Sci., 19, 69-76, 1970.

Kaufman, Y. J., Gobbi, G. P., and Koren, I.: Aerosol climatology using a tunable spectral variability cloud screening of AERONET data, Geophys. Res. Lett., 33, L07817, doi:10.1029/2005GL025478, 2006.

Klein, H., Nickovic, S., Haunold, W., Bundke, U., Nillius, B., Ebert, M., Weinbruch, S., Schuetz, L., Levin, Z., Barrie, L. A., and Bingemer, H.: Saharan dust and ice nuclei over Central Europe, Atmos. Chem. Phys., 10, 10211-10221, doi:10.5194/acp10-10211-2010, 2010a.

Klein, H., Haunold, W., Bundke, U., Nillius, B., Wetter, T., Schallenberg, S., and Bingemer, H.: A new method for sampling of atmospheric ice nuclei with subsequent analysis in a static diffusion chamber, Atmos. Res., 96, 218-224, 2010 b.

Kulkarni, G. and Dobbie, S.: Ice nucleation properties of mineral dust particles: determination of onset $\mathrm{RHi}$, IN active fraction, nucleation time-lag, and the effect of active sites on contact angles, Atmos. Chem. Phys., 10, 95-105, doi:10.5194/acp-10-95-2010, 2010 . 
Kumai, M.: Snow crystals and the identification of the nuclei in the northern United States of America, J. Meteorol., 18, 139-150, 1961.

Kumai, M.: Identification of nuclei and concentrations of chemical species in snow crystals sampled at South Pole, J. Atmos. Sci., 33, 833-841, 1976.

Ladino, L., Stetzer, O., Lüönd, F., Welti, A., and Lohmann, U.: Contact freezing experiments of kaolinite particles with cloud droplets, J. Geophys. Res., 116, D22202, doi:10.1029/2011JD015727, 2011.

Lelieveld, J., Berresheim, H., Borrmann, S., Crutzen, P. J., Dentener, F. J., Fischer, H., Feichter, J., Flatau, P. J., Heland, J., and Holzinger, R.: colleagues: Global air pollution crossroads over the Mediterranean, Science, 298, 794-799, 2002.

Levi, Y. and Rosenfeld, D.: Ice nuclei, rainwater chemical composition, and static cloud seeding effects in Israel, J. Appl. Meteorol., 35, 1494-1501, 1996.

Levin, Z. and Lindberg, J. D.: Size distribution, chemical composition, and optical properties of urban and desert aerosol in Israel, J. Geophys. Res., 84, 6941-6950, 1979.

Levin, Z. and Yankofsky, S. A.: Contact versus immersion freezing of freely suspended droplets by bacterial ice nuclei, J. Clim. Appl. Meteorol., 22, 1964-1966, 1983.

Levin, Z., Joseph, J. H., and Mekler, Y.: Properties of Sharav (Khamsin) dust - comparison of optical and direct sampling data, J. Atmos. Sci., 37, 882-891, 1980.

Levin, Z., Yankofsky, S. A., Pardess, D., and Magal, N.: Possible Application of bacterial condensation freezing to artificial rainfall enhancement, J. Clim. Appl. Meteorol., 26, 1188-1197, 1987.

Levin Z., Price C., and Ganor, E.: The contribution of sulfate and desert aerosol to the acidification of cloud and rain in Israel, Atmos. Environ., 24, 1143-1151, 1990.

Levin, Z., Ganor, E., and Gladstein, V.: The effects of desert particles coated with sulfate on rain formation in the eastern Mediterranean, J. Appl. Meteorol., 35, 1511-1523, 1996.

Levin, Z., Teller, A., Ganor, E., and Yin, Y.: On the interactions of mineral dust, sea salt particles and clouds - A Measurement and modeling study from the MEIDEX campaign, J. Geophys. Res., 110, D20202, doi:10.1029/2005JD005810, 2005.

Lohmann, U. and Diehl, K.: Sensitivity Studies of the Importance of Dust Ice Nuclei for the Indirect Aerosol Effect on Stratiform Mixed-Phase Clouds, J. Atmos. Sci., 63, 968-982, 2006.

Lüönd, F., Stetzer, O., Welti, A., and Lohmann, U.: Experimental study on the ice nucleation ability of size-selected kaolinite particles in the immersion mode, J. Geophys. Res., 115, D14201, doi:10.1029/2009JD012959, 2010.

Maki, L. R. and Willoughby, K. J.: Bacteria as biogenic sources of freezing nuclei, J. Appl. Meteorol., 17, 1049-1053, 1978.

Marcolli, C., Gedamke, S., Peter, T., and Zobrist, B.: Efficiency of immersion mode ice nucleation on surrogates of mineral dust, Atmos. Chem. Phys., 7, 5081-5091, doi:10.5194/acp-7-50812007, 2007.

Meyers, M. P., DeMott, P. J., and Cotton, W. R.: New primary ice nucleation parameterizations in an explicit cloud model, J. Appl. Meteorol., 31, 708-721, 1992.

Möhler, O., Field, P. R., Connolly, P., Benz, S., Saathoff, H., Schnaiter, M., Wagner, R., Cotton, R., Krämer, M., Mangold, A., and Heymsfield, A. J.: Efficiency of the deposition mode ice nu- cleation on mineral dust particles, Atmos. Chem. Phys., 6, 30073021, doi:10.5194/acp-6-3007-2006, 2006.

Murray, B. J., Broadley, S. L., Wilson, T. W., Atkinson, J. D., and Wills, R. H.: Heterogeneous freezing of water droplets containing kaolinite particles, Atmos. Chem. Phys., 11, 4191-4207, doi:10.5194/acp-11-4191-2011, 2011.

Murray, B. J., O’Sullivan, D., Atkinson, J. D., and Webb, M. E.: Ice nucleation by particles immersed in supercooled cloud droplets, Chem. Soc. Rev., 41, 6519-6554, doi:10.1039/c2cs35200a, 2012.

Niedermeier, D., Hartmann, S., Shaw, R. A., Covert, D., Mentel, T. F., Schneider, J., Poulain, L., Reitz, P., Spindler, C., Clauss, T., Kiselev, A., Hallbauer, E., Wex, H., Mildenberger, K., and Stratmann, F.: Heterogeneous freezing of droplets with immersed mineral dust particles - measurements and parameterization, Atmos. Chem. Phys., 10, 3601-3614, doi:10.5194/acp-10-36012010, 2010.

Niedermeier, D., Shaw, R. A., Hartmann, S., Wex, H., Clauss, T., Voigtländer, J., and Stratmann, F.: Heterogeneous ice nucleation: exploring the transition from stochastic to singular freezing behavior, Atmos. Chem. Phys., 11, 8767-8775, doi:10.5194/acp11-8767-2011, 2011.

Petters, M. D., Parsons, M. T., Prenni, A. J., DeMott, P. J., Kreidenweis, S. M., Carrico, C. M., Sullivan, A. P., McMeeking, G. R., Levin, E., Wold, C. E., Collett, J. L., and Moosmuller, H.: Ice nuclei emissions from biomass burning, J. Geophys. Res., 114, D07209, doi:10.1029/2008JD011532, 2009.

Philips, V. T. J., DeMott, P. J., and Andronache, C.: An empirical parameterization of heterogeneous ice nucleation for multiple chemical species of aerosol, J. Atmos. Sci., 65, 2757-2783, 2008.

Pinti, V., Marcolli, C., Zobrist, B., Hoyle, C. R., and Peter, T.: Ice nucleation efficiency of clay minerals in the immersion mode, Atmos. Chem. Phys., 12, 5859-5878, doi:10.5194/acp-12-58592012, 2012.

Pitter, R. L. and Pruppacher, H. R.: A wind tunnel investigation of freezing of small water drops falling at terminal velocity in air, Q. J. Roy. Meteor. Soc., 99, 540-550, 1973.

Pratt, K. A., Murphy, S. M., Subramanian, R., DeMott, P. J., Kok, G. L., Campos, T., Rogers, D. C., Prenni, A. J., Heymsfield, A. J., Seinfeld, J. H., and Prather, K. A.: Flight-based chemical characterization of biomass burning aerosols within two prescribed burn smoke plumes, Atmos. Chem. Phys., 11, 1254912565, doi:10.5194/acp-11-12549-2011, 2011.

Prenni, A. J., Demott, P. J., Rogers, D. C., Kreidenweis, S. M., Mcfarquhar, G. M., Zhang, G., and Poellot, M. R.: Ice nuclei characteristics from M-PACE and their relation to ice formation in clouds, Tellus, 61, 436-448, 2009a.

Prenni, A. J., Petters, M. D., Kreidenweis, S. M., Heald, C. L., Martin, S. T., Artaxo, P., Garland, R. M., Wollny A. G., and Pöschl, U.: Relative roles of biogenic emissions and Saharan dust as ice nuclei in the Amazon basin, Nat. Geosci., 2, 402-405, 2009 b.

Prenni, A. J., DeMott, P. J., Sullivan, A. P., Sullivan, R. C., Kreidenweis, S. M., and Rogers, D. C.: Biomass burning as a potential source for atmospheric ice nuclei: Western wildfires and prescribed burns, Geophys. Res. Lett., 39, L11805, doi:10.1029/2012GL051915, 2012.

Pruppacher, H. R. and Klett, J. D.: Microphysics of Clouds and Precipitation, Kluwer, Norwell, 1997. 
Roberts, P. and Hallett, J: A laboratory study of the ice nucleating properties of some mineral particulates, Q. J. Roy. Meteor. Soc., 94, 25-34, 1968.

Salam, A., Lohmann, U., and Lesins, G.: Ice nucleation of ammonia gas exposed montmorillonite mineral dust particles, Atmos. Chem. Phys., 7, 3923-3931, doi:10.5194/acp-7-3923-2007, 2007.

Santachiara, G., Di Matteo, L., Prodi, F., and Belosi, F.: Atmospheric particles acting as Ice Forming Nuclei in different size ranges, Atmos. Res., 96, 266-272, 2010.

Sarnat, J. A., Moise, T., Shpund, J., Yang, L., Pachon, J. E., Qasrawi, R., Abdeen, Z., Brenner, S., Nassar, K., Saleh, R., and Schauer, J. J.: Assessing the spatial and temporal variability of fine particulate matter components in Israeli, Jordanian, and Palestinian cities, Atmos. Environ., 44, 2383-2392 2010.

Schnell, R. and Vali, G.: Biogenic Ice Nuclei: Part I. Terrestrial and Marine Sources, J. Atmos. Sci., 33, 1554-1564, 1976.

Schnell, R. C., Pueschel, R. F., and Wellman D. L.: Ice nucleus characteristics of Mount St. Helens effluents, J. Geophys. Res., 87, 11109-11112, 1982.

Seifert, M., Ström, J., Krejci, R., Minikin, A., Petzold, A., Gayet, J.F., Schumann, U., and Ovarlez, J.: In-situ observations of aerosol particles remaining from evaporated cirrus crystals: Comparing clean and polluted air masses, Atmos. Chem. Phys., 3, 10371049, doi:10.5194/acp-3-1037-2003, 2003.

Seifert, P., Ansmann, A., Mattis, I., Wandinger, U., Tesche, M., Engelmann, R., Müller, D., Perez, C., and Haustein, K.: Saharan dust and heterogeneous ice formation: Eleven years of cloud observations at a central European EARLINET site, J. Geophys. Res., 115, D20201, doi:10.1029/2009JD013222, 2010.

Twohy, C. H. and Poellot, M. R.: Chemical characteristics of ice residual nuclei in anvil cirrus clouds: evidence for homogeneous and heterogeneous ice formation, Atmos. Chem. Phys., 5, 2289 2297, doi:10.5194/acp-5-2289-2005, 2005.
Vali, G.: Filetr-elutriition experiments for the measurement of airborne freezing nuclei, J. Rech. Atmos., 3, 175-177, 1968.

Vali, G.: Quantitative evaluation of experimental results on the heterogeneous freezing nucleation of supercooled liquids, J. Atmos. Sci., 28, 402-409, 1971.

Vali, G.: Repeatability and randomness in heterogeneous freezing nucleation, Atmos. Chem. Phys., 8, 5017-5031, doi:10.5194/acp-8-5017-2008, 2008.

Van den Heever, S. C., Carrio, G. G., Cotton, W. R., DeMott, P. J., and Prenni, A. J.: Impacts of nucleating aerosol on Florida convection. Part I: Mesoscale Simulations, J. Atmos. Sci., 63, 1752-1775, 2006.

von Schneidemsser, E., Zhou, J., Stone, E. A., Schauer, J. J., Shpund, K., Brenner, S., Barakat, R., Abdeen, Z., and Sarnat, J. A. Spatial Variability of Carbonaceous Aerosol Concentrations in East and West Jerusalem, Environ. Sci. Technol., 44, 1911-1917, 2010.

Welti, A., Lüönd, F., Stetzer, O., and Lohmann, U.: Influence of particle size on the ice nucleating ability of mineral dusts, Atmos. Chem. Phys., 9, 6705-6715, doi:10.5194/acp-9-6705-2009, 2009.

Welti, A., Lüönd, F., Kanji, Z. A., Stetzer, O., and Lohmann, U.: Time dependence of immersion freezing: an experimental study on size selected kaolinite particles, Atmos. Chem. Phys., 12, 9893-9907, doi:10.5194/acp-12-9893-2012, 2012.

Zhang, D., Wang, Z., Heymseld, A., Fan, J., Liu, D., and Zhao, M. Quantifying the impact of dust on heterogeneous ice generation in midlevel supercooled stratiform clouds, Geophys. Res. Lett., 39, L18805, doi:10.1029/2012GL052831, 2012.

Zimmermann, F., Weinbruch, S., Schütz, L., Hofmann, H., Ebert, M., Kandler, K., and Worringen, A.: Ice nucleation properties of the most abundant mineral dust phases, J. Geophys. Res., 113, D23204, doi:10.1029/2008JD010655, 2008. 